\title{
Bovine Respiratory Disease (BRD) Complex as a Signal for Bovine Viral Diarrhea Virus (BVDV) Presence in the Herd
}

\author{
Natália Sobreira Basqueira', Camila Cecilia Martin', Juliana França dos Reis Costa', Líria Hiromi Okuda², \\ Maristela Edviges Pituco' ${ }^{2}$, Camila Freitas Batista', Alice Maria Melville Paiva Della Libera' \& Viviani Gomes'
}

\begin{abstract}
Background: Infections are caused by Bovine Viral Diarrhea Virus and still continue to be a worldwide plague in cattle industry. It is responsible for sudden death syndromes in adult cattle with high mortality rates, abortions, acute gastrointestinal and respiratory diseases. The BVDV infection occurs in early pregnancy (40-142 days), in immunosuppressed females or cows results in $100 \%$ of persistently infected (PI) calves that are seronegative and asymptomatic at birth. Evidences suggests that BVDV contributes to BRD complex potentiating secondary infections caused by Mannheimia haemolytica e Pasteurella multocida due to its immunosuppressive action. However, the farmers have often associated the respiratory syndrome with other infectious agents. This paper reports the attendance of dairy calves manifesting clinical signs of bronchopneumonia, which led to the screening of the persistently infected animals to control of the BVDV infection in the herd.

Materials, Methods \& Results: During the technical assistance, ten calves manifesting bronchopneumonia were selected to trans-tracheal lavage (TL) in order to identify possible infectious agents. Reverse transcription polymerase chain reaction (RT-PCR) detected the presence of BVDV in two heifers. Pasteurella multocida was the unique bacterial agent isolated from TL $(5 / 10,50 \%)$. These data motivated the technical team and producers to investigate the PI screening by direct enzyme-linked immunosorbent assay from biopsies of the ear edge. The screening of PI's detected 29 positive within of 2,342 animals tested $(1.23 \%)$. The re-test of positive was performed only in 24 animals due to the cull of five bovine with severe bronchopneumonia and diarrhea, confirming 18 persistently infected calves (18/24; 75\%). Finally, in all PI's live dams were tested. It was observed four positive adult animals. One grand dam was live and tested, but it had negative result for direct enzyme-linked immunosorbent test. The rate of PI's considering the whole herd was $0.81 \%(22 / 3,700$ animals). Discussion: The involvement of BVDV in the etiology of bronchopneumonia was confirmed by detection of the virus in trans-tracheal lavages in two calves by RT-PCR. The susceptibility for Pasteurella multocida infection could be promoted by BVDV prime-infection, considering that immunossupressive nature of BVDV is a critical factor in the interaction with others viruses and bacteria. At this time, we are aware about any report about the detection of BVDV in trans-tracheal lavages. These findings culminated with the screening of PI animals in the herd, detecting rates of $0.81 \%$.

The intensive vaccination and colostrum management of this farm could protected the herd against BVDV, however others facts facilitated the introduction of the virus in the herd. This research was conduced in a high-production dairy farm with around 3,700 animals raised in an open herd, in which some of cows with high genetic potential were transferred for embryo collection in the state of Paraná, Brazil; resulting in the addition of the calves to the herd by others routes. Moreover, the farm used for many years vaccine containing only BVDV-1, which may have favored the entry and spread of BVDV-2 or BVDV-3 in the herd. This research showed the presence of BVDV in trans-tracheal lavage of heifers with bronchopneumonia by RT-PCR. This fact points to the need of BRD control programs that include detection of PI animals.
\end{abstract}

Keywords: RT- PCR, direct enzyme immunoassay test, Pasteurella multocida.

'Department of Internal Medicine, College of Veterinary Medicine and Animal Science - University of São Paulo (USP), São Paulo, SP, Brazil. ${ }^{2}$ Biological Institute - Laboratory of Bovine Viruses, São Paulo, SP. CORRESPONDENCE: V. Gomes [viviani.gomes@ usp.br - Tel.: +55 (11) 30911331 ]. Department of Internal Medicine, College of Veterinary Medicine and Animal Science - University of São Paulo (USP). Av. Prof. Dr. Orlando Marques de Paiva n. 87. Cidade Universitária, Butantã. CEP 05508-270 São Paulo, SP, Brazil. 


\section{INTRODUCTION}

Infections are caused by Bovine Viral Diarrhea Virus and still continue to be a worldwide plague in cattle industry. It is responsible for sudden death syndromes in adult cattle with high mortality rates, abortions, acute gastrointestinal and respiratory diseases [12]. The economic losses for BVDV in the United States were estimated between U\$ 460 up to 767 million per year [7].

The BVDV belongs to Flaviviridae family and Pestivirus genus. This agent has ribonucleic acid as genetic material and it is classified in two biotypes, based on its ability to produce cytopathic effects in cell culture and genetic sequencing: non cytopathogenic (NCP) and cytopathogenic (CP), and genotypes: BVDV-1 and BVDV- 2. Moreover, Pestivirus atypical was isolated in Brazil some years ago in a fetal bovine serum sample and has been called as Hobi-like [2].

The BVDV infection in early pregnancy (40142 days), in immunosuppressed females or cows results in $100 \%$ of persistently infected (PI) calves. PI animals are seronegative and asymptomatic at birth, but they are constantly eliminating the virus in all its secretions and excretions $[9,10]$.

Evidence suggests that BVDV contributes to BRD complex potentiating secondary infections caused by Mannheimia haemolytica and Pasteurella multocida due to its immunosuppressive action. This immunosuppression affects many different components of the innate system such as interferon production, phagocytosis, chemotaxia, microbicidal activity. In relation to the specific immune system, BVDV CP and NCP can kill (by apoptosis) $\mathrm{T}$ and $\mathrm{B}$ cells in lymphoid tissues. There is negative effect of BVDV infection on Thelper response. The activation of the $\mathrm{T}$ helper 2 responses by NCP BVDV provides another mechanism that also affects acquired and innate immunity. The helper 2 response suppresses the T helper 1 memory response and also suppresses the phagocytic and microbicidal activity of macrophages. No one genotype (type 1 vs. type 2) or biotype (noncytophatic vs. cytophatic) produces the same effects on the immune system. This immunosuppression can last up 3-4 weeks. Both humoral and cellular mediate immune responses are important in the BVDV infection [3,4].

The unspecific symptomatology of BVDV is the first challenge to prove the impact of the virus infection in the production system, because the producers often associated the syndrome caused by BVDV with other infectious agents. So, farmers do not investigate PI's screening. In Brazil, it is more serious due to the inexistence of an official program for BVDV control. These facts were the motivation for the description of a practical work realized in the biggest dairy farm located in the countryside of São Paulo state. This work culminated with the consciousness of the technical team and producer to proceed with PI screening in the herd.

This paper reports the attendance of dairy calves manifesting clinical signs of bronchopneumonia, which led to the screening of the persistently infected animals to control the BVDV infection in the herd.

\section{MATERIALS AND METHODS}

\section{Herd identification and installations}

This work was conduced in a commercial dairy herd of high production, average of $66,000 \mathrm{~L}$ of milk/day, located in the countryside of Sao Paulo. The herd consists of approximately 3,700 Holstein cows, of which 1,750 were dairy cows with average daily production of $38.5 \mathrm{~L}$. Suckler heifers aged from 1 to 60 days, approximately 95 animals, were housed in individual suspended cages with approximately $1 \mathrm{~m}^{2}$, distributed in covered shed with an area of $112.5 \mathrm{~m}^{2}$ and a height of $4.5 \mathrm{~m}\left(1.18\right.$ unit animal $\left./ \mathrm{m}^{2}\right)$. After this period, animals were moved to confinement pasture and remained until 30 days of the expected day and then they were transferred to the maternity pasture. Dairy cows were housed in the shed with cross ventilation system. During the dry period, the animals were kept in barns of the free-stall type.

The births were assisted and calves were separated immediately after calving and transferred to individual pen. Four L of colostrum of the first milking were administered into 2 feedings during the first $12 \mathrm{~h}$ after birth. The colostrum was from multiparous donors, whose immune quality was estimated by colostrometer ( $\geq 50 \mathrm{~g} / \mathrm{L}$ of immunoglobulin). The thawing was performed in a water bath $\left(45-50^{\circ} \mathrm{C}\right)$ until the colostrum reach $37^{\circ} \mathrm{C}$. Then, calves were fed with 6 $\mathrm{L}$ of milk replacer per day.

The farm vaccination protocol begins at the creating stage by 60 days of life and the animals receive booster at 90 days, followed by semiannual revaccination held in April and October. The commercial vaccine used contains inactivated strains of BVDV 
type 1; BHV-1 and PI-3; BRSV, and Leptospira spp., associated with aluminum hydroxide as adjuvants.

Approach of calves with bronchopneumonia

The first technical visit in this farm was realized in August 2013. The technical team from farm requested clinical assistance due to the high incidence of bronchopneumonia and failure in the treatment with antibiotics.

First of all, 10 heifers manifesting bronchopneumonia, between 45 to 60 days of life, were selected to procedure clinical examination and laboratorial exams. Bronchopneumonia was scored using the following parameters: rectal temperature, cough, nasal and ocular secretion and ear position with a score of 0-3 for each based on severity. Calves were assessed as having bronchopneumonia when the sum of these scores was $>5$. Bronchopneumonia scores in according to Calf Heath Scoring Criteria previously published by The University of Wisconsin (Madison) [14].

Trans-tracheal lavage was obtained by puncturing the trachea in its middle third, with a trocar of 2.1 $\mathrm{mm}$ diameter and $5.1 \mathrm{~cm}$ length, in which was inserted a polyethylene catheter of $1.7 \mathrm{~mm} \times 20.3 \mathrm{~cm}$ (Intracath, $\mathrm{BD})$. Then, $40 \mathrm{~mL}$ of $0.9 \%$ saline were instilled into the trachea and the contents were immediately recovered by aspiration with a syringe. The samples were placed in 2 sterile tubes for bacteriological and reverse transcription polymerase chain reaction.

Serum samples were used for detection of neutralizing antibodies to Bovine Respiratory Syncytial Virus (BRSV), BVDV and Bovine Herpesvirus type 1 (BHV-1) by VN in accordance to OIE (2015).

Trans-tracheal lavage was inoculated in Brain Heart Infusion (BHI), blood agar (5\%) and MacConkey, incubated at $37^{\circ} \mathrm{C}$ for 24 to $48 \mathrm{~h}$ [15]. Susceptibility test was performed in vitro to antibiotics [1].

For RT-PCR, the RNA extracted in transtracheal lavage was tested using TRIZOL LS ${ }^{\circledR}$ (Invitrogen ${ }^{1}$ ). Reverse transcription followed by polymerase chain reaction was performed according to the manufacturer's recommendations (Accessquick PCR Master mix $^{\circledR}$, PROMEGA $\left.^{2}\right)$. The primers used in the reaction detected common regions for BVDV 1, 2 and Hobilike, based on a sequence of 290 nucleotides, located in the 5' non-translated region (5' TAG CCA TGC CCT TAG TAG GAC 3' e 5' ACT CCA TGT GCC ATG TAC AGC 3') according Weinstock et al. [18]. Amplicons were detected by electrophoresis on $1.5 \%$ agarose gel stained by diluted GelRed ${ }^{4}$ (1:150) in nuclease free water. The visualization was performed using a transilluminator under ultraviolet light $(320 \mathrm{~nm})$. The DNA fragments were compared with the standard base pairs presenting increments of $100 \mathrm{pb}$ (DNA Ladder of 100 $\mathrm{pb}^{\circledR}$, Invitrogen $\left.^{1}\right)$.

\section{Detection of persistently infected (PI) animals}

The evidences of the presence of BVDV in the first visit, associated to the high levels of specific antibodies in the bulk tank milk convinced the technical team from the farm and producers to invest in the detection of persistently infected (PI) animals. It was a long process between 2013 until 2015. The data from the first visit will be present in the appropriate topic.

The first visit for PI detection was realized in September $9^{\text {th }}$ and $10^{\text {th }}, 2013$. Ear biopsy was performed in 2,342 animals, contemplating the latest generation of females, dairy cows that calved only male or those without living descendants.

The re-tested in the positive or suspicious results in the direct enzyme immunoassay test were realized in October $13^{\text {th }}$, to distinguish between transient and persistent infection. In October $29^{\text {th }}$, dams $(n=4)$ and grand dam $(n=1)$ of PI animals were also submitted to the same protocol described previously.

The direct enzyme-linked immunosorbent assay was performed from biopsies of the ear edge. The fragment was obtained with approximately $1.0 \mathrm{~cm}$ long and $0.5 \mathrm{~cm}$ wide, using the ear notch biopsy and kept in microtubes. Among each harvest, the material was disinfected with $70 \%$ ethanol. The direct enzyme linked immunosorbent assay was performed using a commercial kit following the manufacturer's instructions (Bovine Virus Diarrhoea Virus - Antigen Test Kit/Serum Plus ${ }^{\circledR 3}$ ).

\section{RESULTS}

The individual results obtained in the first visit performed in August/2013 with high rates of bronchopneumonia in calves are shown in the Table 1. The minimum and maximum values of antibody titers oscillated from 4 to 512 for BHV-1; 40 to 5,120 for BVDV; and 32 to 256 for BRSV. Moreover, RTPCR detected the presence of BVDV in trans-tracheal lavage from two heifers that presented titers of 40 and 640 for BVDV, and only one of them had concomitant infection by Pasteurella multocida. 
Pasteurella multocida was the unique bacterial agent isolated from trans-tracheal lavage $(5 / 10,50 \%)$, observing resistance for the following antimicrobials: amikacin $(30 \mu \mathrm{g})$, ampicillin $(10 \mu \mathrm{g})$, amoxicillin + clavulanic acid $(10 \mu \mathrm{g})$, gentamicin $(10 \mu \mathrm{g})$, neomycin $(30 \mu \mathrm{g})$ and trimethoprim + sulfamethoxazole $(25 \mu \mathrm{g})$. On the other hand, it was possible to observe sensibility of strains for the following antimicrobials: cephalexin $(30 \mu \mathrm{g})$, cephalothin $(30 \mu \mathrm{g})$, cefoxitin $(30 \mu \mathrm{g})$, ceftiofur $(30 \mu \mathrm{g})$, ciprofloxacin $(5 \mu \mathrm{g})$, enrofloxacin $(5 \mu \mathrm{g})$, norfloxacin $(10 \mu \mathrm{g})$ and tetracycline $(30 \mu \mathrm{g})$.

The presence of BVDV in trans-tracheal lavage was the first motivation to perform the screening of PI in the herd. These results motivated the screening of PI's animals in the herd.
The first test for BVDV, realized in 2013, September $9^{\text {th }}$ and $10^{\text {th }}$, detected $1.24 \%(29 / 2,342)$ positives within 2,342 animals tested. The re-test of positive animals in October $12^{\text {th }}$, was performed only in 24 animals due to the cull of 5 bovine with severe bronchopneumonia and diarrhea, confirming 18 persistently infected calves $(18 / 24 ; 75 \%)$. Finally, all live dams of PI's were tested, observing 4 positive adult animals (Table 2). One grand dam was also tested, but it had negative result for direct enzyme-linked immunosorbent test. The rate of PI's considering the whole herd was $0.81 \%(22 / 3,700$ animals).

It is worth emphasizing that one of the calves diagnosed with PI in the second stage had presented positive RT-PCR for BVDV in trans-tracheal lavage.

Table 1. Serum titers of neutralizing antibodies, RT-PCR and infectious agents detected in the trans-tracheal lavage of Holstein heifers expressing BRD.

\begin{tabular}{|c|c|c|c|c|c|}
\hline \multirow{2}{*}{ Animal } & \multicolumn{3}{|c|}{ Serum neutralization } & \multirow{2}{*}{$\begin{array}{c}\text { RT-PCR } \\
\text { BVDV }\end{array}$} & \multirow{2}{*}{ Bacteriological Examination } \\
\hline & BHV-1 & BVDV & BRSV & & \\
\hline 1 & 32 & 5120 & 64 & \multirow{10}{*}{$\begin{array}{c}\text { Negative } \\
\text { Positive } \\
\text { Negative } \\
\text { Negative } \\
\text { Positive } \\
\text { Negative } \\
\text { Negative } \\
\text { Negative } \\
\text { Negative } \\
\text { Negative }\end{array}$} & Negative \\
\hline 2 & 4 & 640 & 128 & & Pasteurella multocida \\
\hline 3 & 512 & 5120 & 256 & & Pasteurella multocida \\
\hline 4 & 64 & 320 & $*$ & & Pasteurella multocida \\
\hline 5 & 8 & 40 & 128 & & Negative \\
\hline 6 & 256 & 80 & 32 & & Negative \\
\hline 7 & 64 & 1280 & 128 & & Pasteurella multocida \\
\hline 8 & 32 & 640 & 32 & & Negative \\
\hline 9 & 32 & 320 & 64 & & Pasteurella multocida \\
\hline 10 & 4 & 640 & 64 & & Negative \\
\hline
\end{tabular}

*Insufficient sample.

Table 2. Results obtained for PI's screening in a dairy farm according to the Direct enzyme-linked immunosorbent assay.

\begin{tabular}{|c|c|c|c|}
\hline Dates/2015 & Number of tested animals & Positive results & Frequency $(\%)$ \\
\hline Screening (September 9 and 10$)^{*}$ & 2,342 & 29 & $1.24 \%$ \\
\hline Re-test (October 13) ${ }^{* *}$ & $24^{* * *}$ & 18 & $75 \%$ \\
\hline Dams test (October 29) $)^{* * * *}$ & 4 & 4 & $100 \%$ \\
\hline Granddam (October 29) (***** $^{* * *}$ & 1 & 0 & $0 \%$ \\
\hline
\end{tabular}

*For BVDV screening were tested the latest generation of females, dairy cows that calved only male or those without living descendants; **live positive animals were re-tested around 30 days after the screening; *** five animals were culled due to intense bronchopneumonia and diarrhea; ****live dams of PI's were tested for BVDV; ******live granddam tested. 


\section{DISCUSSION}

This study initially was conducted according to the request of the producer with the initial objective was identify possible etiological agents involved in BRD due to its high incidence and rate of failure in treatment with antimicrobials.

The main etiologic agents detected in transtracheal lavage were BVDV associated with Pasteurella multocida. The involvement of BVDV in BRD is consensual due to the detection of genetic material of this virus in trans-tracheal lavage from dead animals obtained in slaughterhouses or necropsies [5,19]. On the other hand, the identification of this agent in trans-tracheal lavage from live heifers presenting bronchopneumonia had not yet been reported. This method could be used to identify BVDV involvement in animals manifesting bronchopneumonia. It is believed the hypothesis that the sensitivity of detection of BVDV by RT-PCR on the trans-tracheal washed is greater than those made from blood leukocytes due to the restriction of the inflammatory process in lungs.

The susceptibility for Pasteurella multocida infection found in this report could be promoted for BVDV prime-infection. The association between BVDV and Pasteurella multocida was also identified in material from nasal swab by RT-PCR in healthy heifers [8]. Probably no virus involved with BRD has received as much research attention since 1983 as BVDV [17]. The immunossupressive nature of BVDV is a critical factor in the interaction of BVDV with others viruses and bacteria, especially in BRD [4,6].

The role of BVDV in mixed infections in respiratory tract is not yet fully elucidated, inquiring if the main importance of this agent in the respiratory environment is linked only to its immunosuppressive action due to infection of leukocytes that participate in innate and specific immune response of mucous in respiratory tract [6].

High levels of serum antibodies were detected for BVDV and BRSV in the investigated heifers; however, 3 calves had antibody titers to BHV-1 below of the protective value equivalent to 32 . It is not possible to affirm that the antibodies detected in the serum neutralization were obtained passively by ingestion of colostrum or because of active immunity due to the circulation of the virus in the herd. The presence of maternal antibodies makes unfeasible the use of serum neutralization for the diagnosis of BVDV before 10 weeks of life [11].
The BVDV detection in trans-tracheal lavage was the first evidence of the BVDV infection in this herd. Among 2013 to 2016, others events were happening enforce the evidence of PI's presence in the farm, such as seropositive calves identification before colostrum intake [13]; and high levels of specific antibodies for BVDV in the bulk tank milk. These facts motivated the technical team and producers to invest in PI screening.

The rate of PI's observed was low $(0.81 \%)$, comparing with the values reported in the literature $(1-2 \%)$ [16]. The intensive vaccination and colostrum management of this farm could be protected the herd against BVDV, however others facts facilitated the introduction of the virus in the herd. This research was conduced in a high-production dairy farm with around 3,700 animals raised in an open herd, in which some of cows with high genetic potential were transferred for embryo collection in Paraná, Brazil, resulting in the addition of the calves to the herd by others routes. In addition, the farm used for many years vaccine containing only BVDV-1, which may have favored the entry and spread of BVDV-2 or BVDV-3 in the herd.

The main cause of cull in PI animals during this study was bronchopneumonia. It is worth remembering that one of the animals diagnosed as PI during the screening of herd had presented positive RT-PCR for BVDV in trans-tracheal lavage. The farmers maintained these heifers in the herd from 2013 up to 2016, when the diagnosis of PI was realized.

BRD is certainly one of the most important diseases in the world, so it is very important to know the main risk factors and etiologic agents involved in etiopathogenesis of the disease for the establishment of treatment protocols, and more efficient and specific prevention and control protocols. Generally, treatment protocols are based on the use of antibiotics, although viruses may represent the primary cause of bronchopneumonia. This research showed the presence of BVDV trans-tracheal lavage in heifers presenting bronchopneumonia by RT-PCR. This fact points to the need for BRD control programs that include detection of PI animals.

\section{CONCLUSION}

The identification of BVDV in trans-tracheal lavage by RT-PCR in heifers manifesting bronchopneumonia could be used to prove the involvement of this virus in BRD complex. It could be considered an alert to perform the screening of PI's in the herd to directly control of BVDV and indirectly control of secondary agents. 
MANUFACTURERS

${ }^{1}$ Thermo Fisher Scientific Inc. Waltham, MA, USA.

${ }^{2}$ Promega Corporation. Madison, WI, USA.

${ }^{3}$ IDEXX Laboratories. Westbrook, ME, USA.

${ }^{4}$ GelRed Biotium. Hayward, CA, USA

Funding. This research was supported by grants from São Paulo Research Foundation (FAPESP) [Project number 2012/02129-8].
Ethical approval. All applicable international, national, and/ or institutional guidelines for the care and use of animals were followed.

Declaration of interest. The authors declare that there is no conflict of interest that could be perceived as prejudicing the impartiality of the research reported.

\section{REFERENCES}

1 Bauer A.W., Kirby W.M., Sherris J.C. \& Turck M. 1966. Antibiotic susceptibility testing by a standardized single disk method. American Journal of Clinical Pathology. 45(4): 493-496.

2 Bianchini E., Martins M., Weiblen R. \& Flores E.F. 2001. Perfil genotípico e antigênico de amostras do vírus da diarréia viral bovina isoladas no Rio Grande do Sul (2000-2010). Pesquisa Veterinária Brasileira. 31(8): 649-655.

3 Chase C.C.L., Elmowalid G. \& Yousif A.A. 2004. The imune response to bovine viral diarrhea vírus: a constantly changing Picture. Veterinary Clinics Food Animal Practice. 20(1): 95-114.

4 Chase C.C.L., Thakur N., Darweesh M.F., Morarie-Kane S.E. \& Rajput M.K. 2015. Immune response to bovine viral diarrhea virus - looking at newly defined targets. Animal Health Research Reviews. 11(1): 4-14.

5 Fulton R.W. 2009. Bovine respiratory disease research (1983-2009). Animal Health Research Reviews. 10(2): 131-139.

6 Fulton R.W., Purdy C.W., Confer A.W., Saliki J.T., Loan R.W., Briggs R.E. \& Burge L.J. 2000. Bovine viral diarrhea viral infections in feeder calves with respiratory disease: interactions with Pasteurella spp., parainfluenza-3 virus, and bovine respiratory syncytial virus. Canadian Journal of Veterinary Research. 64(3): 151-159.

7 Givens M.D. \& Newcomer B.W. 2015. Perspective on BVDV control programs. Animal Health Research Reviews. 16(01): 78-82.

8 Hotchkiss E.J., Dagleish M.P., Willoughby I.J., McKendrick J., Finlayson R.N., Newsome E., Brulisauer F., Gunn G.J. \& Hodgson J.C. 2010. Prevalence of Pasteurella multocida and other respiratory pathogens in the nasal tract of Scottish calves. Veterinary Record. 167: 555-560.

9 Kelling C.L. \& Topliff C.L. 2013. Bovine maternal, fetal and neonatal responses to bovine viral diarrhea virus infections. Biologicals. 41(1): 20-25.

10 Lanyon S.R., Hill F.H., Reichel M.P. \& Brownlie J. 2014. Bovine viral diarrhoea: Pathogenesis and diagnosis. The Veterinary Journal. 199(2): 201-209.

11 Laureyns J., Ribbens S. \& Kruif A. 2010. Control of bovine virus diarrhea at the herd level: reducing the risk of false negatives in the detection of persistently infected cattle. Veterinary Journal. 184(1): 21-26.

12 Lindberg A.L.E. 2003. Bovine viral diarrhoea virus infections and its control. A review. Veterinary Quarterly. 25: 1-6.

13 Martin C.C., Baccili C.C., Silva B.T., Novo S. M.M., Sobreira N.M., Pituco E.M. \& Gomes V. 2016. Detection of Bovine Viral Diarrhea virus infection in newborn calves before colostrum intake. Semina Ciências Agrarias. 37(3): 1379-1388.

14 Mcguirk S.M. 2008. Disease management of dairy calves and heifers. Veterinary Clinics of North America. 24(1): 139-156.

15 Murray P.R., Baron E.J., Jorgensen J.H., Landry M.L. \& Pfaller M.A. 1999. Manual of Clinical Microbiology. 7th edn. Washington DC: ASM Press, 265p.

16 Pilz D., Alfieri A.F. \& Alfieri A.A. 2005. Comparação de diferentes protocolos para a detecção do vírus da diarréia viral bovina por RT-PCR em grupos de sangue total e de soro sangüíneo, artificialmente contaminados. Semina: Ciências Agrárias. 26(2): 219-228.

17 Ridpath J.F \& Fulton R.W 2009. Knowledge gaps impacting the development of BVDV control programs in the United States. Journal of the American Veterinary Medical Association. 235(10): 1171-1179.

18 Weinstock D., Bhudevi B. \& Anthony E.C. 2001. Single-tube single-reverse transcriptase PCR assay for detection of bovine viral diarrhea virus in pooled bovine serum. Journal of Clinical Microbiology. 39(1): 343-346.

19 Zeitler B. \& Rapp I. 2013. Determination of Infectious Bovine Viral Diarrhea Virus in Bovine Lung Lavages by a Combination of Virus Propagation in Cell Culture and Quantitative Real-Time PCR. IRSN Virology. 2013: 1-9. 